\title{
KONDISI KESEHATAN KARANG FUNGIIDAE DI PERAIRAN PULAU PRAMUKA, KEPULAUAN SERIBU
}

\author{
(CORAL HEALTH CONDITION OF FAMILY OF FUNGIIDAE \\ ON PRAMUKA ISLAND, SERIBU ISLANDS) \\ Beginer Subhan ${ }^{12}$, Fadhilah Rahmawati, Dondy Arafat, Nur Ari Bayu \\ ${ }^{1}$ Corresponding author \\ ${ }^{2}$ Departemen Ilmu dan Teknologi Kelautan \\ Fakultas Perikanan dan Ilmu Kelautan IPB \\ E-mail : begi_ners@yahoo.com
}

\begin{abstract}
This research was done on five sites (that are Southwestward, Marine Protected Area, Northeastward, and pier 1) on Pramuka Island, Seribu Islands, Jakarta. The data was taken by using Belt Transect Method which is unfold type for 60 meters parallels with shoreline, 2 meters in width of visibility, and 5 meters in depth. Kinds of coral that was collected are those from Family of Fungiidae. There are five genera from Family of Fungiidae found in Pramuka Island, that are Heliofungia, Herpolitha, Fungia, Ctenactis, and Sandalolitha. From 106 of total coral's individu of Fungiidae in all sites of Pramuka Island, as much as 38.68\% (41 individuals) of Fungiidae are healthy and as much as 61.32\% (65 individuals) is got disease. Fungia is the most affected by coral disease. 19 of 61 individuals of Fungia (31.15\%) are still healthy and 42 individuals $(68.85 \%)$ affected by coral disease. On 24 individuals of Ctenactis that has found in all station, $70.83 \%$ of them affected by coral disease. From 13 individuals of Herpolitha, 38,46\% of them affected by coral disease and 61,54\% is healthy. From 6 individuals of Sandalolitha, as much as 50\% recorded is affected by coral disease and 50\% is healthy. Heliofungia is the only genera of Fungiidae that is not affected by coral disease in all observation stations on Pramuka Island. Coral disease that identified has attack the Fungiidae are Yellow Band Disease, bleaching (stripes, spots, patches dan full), Sediment Damage, combination between Sediment Damage and Yellow Band Disease, and Enlarge Structure. Yellow Band Disease are the one that most appear, which is represent 67,69\% of the total coral disease in the Fungïdae with the value of disease abundance is 0,37 individu $/ m^{2}$.
\end{abstract}

Keywords : Coral disease, fungiidae, Seribu Islands

\begin{abstract}
ABSTRAK
Penelitian ini dilakukan pada 5 stasiun (yaitu Barat Daya Pramuka, Area Perlindungan Laut, Timur Laut Pramuka, Timur Pramuka, dan Dermaga 1) di Pulau Pramuka, Kepulauan Seribu, Jakarta. Pengambilan data menggunakan metode Belt Transect, yaitu membentangkan roll meter sepanjang 60 meter dengan lebar jarak pandang 2 meter pada kedalaman 5 meter. Karang yang didata adalah karang dari Suku Fungiidae. Marga dari karang Fungiidae yang ditemukan di Pulau Pramuka ada lima, yaitu Heliofungia, Herpolitha, Fungia, Ctenactis, dan Sandalolitha. Dari total 106 individu karang Fungiidae yang ditemukan di 5 stasiun pengamatan di Pulau Pramuka, sebanyak 38,68\% (41 individu) dalam kondisi sehat dan 61,32\% (65 individu) terserang penyakit karang. Fungia merupakan marga karang dari Fungiidae yang paling banyak terkena penyakit karang. 19 dari 61 individu karang Fungia $(31,15 \%)$ masih dalam kondisi sehat dan 42 individu $(68,85 \%)$ terkena penyakit karang. Pada 24 individu karang Ctenactis yang ditemukan di seluruh stasiun, 70,83\% di antaranya terkena penyakit karang. 13 individu Herpolitha, 38,46\% terkena penyakit karang dan 61,54\% dalam kondisi sehat. 6 individu Sandalolitha, sebanyak 50\% didata dalam kondisi terkena penyakit karang dan 50\% dalam kondisi sehat. Heliofungia merupakan satu-satunya marga karang dari Fungiidae di semua stasiun pengamatan di Pulau Pramuka yang tidak ditemukan terjangkit penyakit karang. Penyakit karang yang teridentifikasi menyerang Fungiidae pada kelima stasiun yaitu Yellow Band Disease, pemutihan karang / bleaching (stripes, spots, patches dan menyeluruh), sedimentasi, gabungan antara sedimentasi dan Yellow Band Disease, dan Enlarge Structure. Yellow Band Disease merupakan penyakit karang yang paling banyak muncul, yaitu sebesar 67,69\% dari total penyakit karang yang ditemukan pada Fungiidae dengan nilai kelimpahannya sebesar 0,37 individu/ $\mathrm{m}^{2}$.
\end{abstract}

Kata kunci: Penyakit karang, fungiidae, Pulau Seribu 


\section{PENDAHULUAN}

Kondisi terumbu karang sudah semakin terdegradasi. Penyakit karang (coral disease) diduga sebagai penyebab utama terdegradasinya karang (Porter et al., 2001). Stedman (2000) menjelaskan penyakit sebagai segala yang merusak (gangguan, gencatan, perkembangbiakan atau kekacauan lainnya) dari fungsi penting tubuh, sistem atau organ. Faktor utama lainnya yang berkontribusi terhadap penurunan terumbu karang adalah pemutihan karang (Brown, 1997). Keanekaragaman (biodiversity) karang lebih tinggi di wilayah IndoPasifik daripada di Karibia. Indo-Pasifik memiliki lebih dari $80 \%$ terumbu karang di seluruh dunia dan lebih dari 90\% spesies karang dunia (Bryant et al., 1998). Umur dan luas geografis dari wilayah Indo-Pasifik inilah yang membuat kekayaan (richness) jenis karang yang tinggi (Veron, 1995). Walaupun kekayaan jenis karang lebih besar di Indo-Pasifik, Jumlah jenis karang yang terjangkit penyakit jauh lebih sedikit dibandingkan di Karibia (Sutherland et al., 2004).

Di Karibia, penyakit karang telah terdokumentasi dengan baik, tetapi masih sedikit yang diketahui tentang penyakit karang di Indo-Pasifik. Sudah ada yang meneliti tentang penyakit karang di Sulawesi. Haapkylä et al. (2007) melakukan studi pertama mengenai penyakit karang di Wakatobi, Sulawesi Tenggara, Indonesia. Dalam area seluas $3600 \mathrm{~m}^{2}$, dari 12.352 koloni karang, sebanyak $1.627 \quad(13,2 \%)$ koloninya menunjukkan tanda-tanda patologi, termasuk pemutihan, tandatanda predasi, penyakit dan patologi yang belum diketahui.

Kondisi kesehatan terumbu karang di Kepulauan Seribu masih belum banyak teramati. Suharsono (1998) mengemukakan pendapat bahwa kesehatan terumbu karang Kepulauan Seribu dan dunia pada umumnya, dalam tiga dekade terakhir ini terancam oleh peningkatan suhu permukaan laut akibat El-Nino. Seperti yang telah diungkapkan oleh Hoegh-Guldberg
(1999), perubahan suhu perairan yang ekstrim dapat memicu penyakit karang seperti coral bleaching. Salah satu jenis bakteri yang ditemukan pada karang yang teridentifikasi terkena penyakit karang, Vibrio shiloi, juga sangat bergantung pada suhu untuk dapat tumbuh, yaitu pada suhu $>25{ }^{\circ} \mathrm{C}$ (Banin et al., 2001a). Fungiidae merupakan karang yang sering dimanfaatkan sebagai karang hias. Oleh karena itu lokasi ini dipilih sebagai lokasi pengamatan terhadap penyakit karang khususnya pada Suku Fungiidae.

\section{METODE PENELITIAN}

Penelitian ini dilakukan di Pulau Pramuka, Kepulauan Seribu, Jakarta dengan mengambil data di lima stasiun pengamatan, yaitu Barat Daya Pramuka, Area Perlindungan Laut (APL), Timur Laut Pramuka, Timur Pramuka, dan Dermaga 1.

Pengambilan data menggunakan metode Belt Transect sepanjang 60 meter dengan lebar jarak pandang 2 meter pada kedalaman 5 meter. Karang yang didata adalah karang dari Suku Fungiidae. Semua Fungiidae yang ditemukan dalam luasan Belt Transect $(60 \times 2$ meter) itu didokumentasikan menggunakan kamera bawah air kemudian semua penyakit karang yang ditemukan pada suku ini diidentifikasi dengan merujuk pada Beeden (2008).

Prevalensi (kemerataan) penyakit karang diketahui dengan mencatat jumlah kasus penyakit dan jumlah karang sehat per satuan luas, dimana luas pengamatan pada penelitian adalah $120 \mathrm{~m}^{2}$. Persamaan prevalensi ini digunakan untuk melihat kemerataan penyakit karang yang terdapat pada suku Fungiidae.

Kelimpahan (abundance) penyakit karang dihitung berdasarkan pembagian jumlah karang yang terkena suatu jenis penyakit dengan jumlah seluruh karang yang terkena penyakit. 


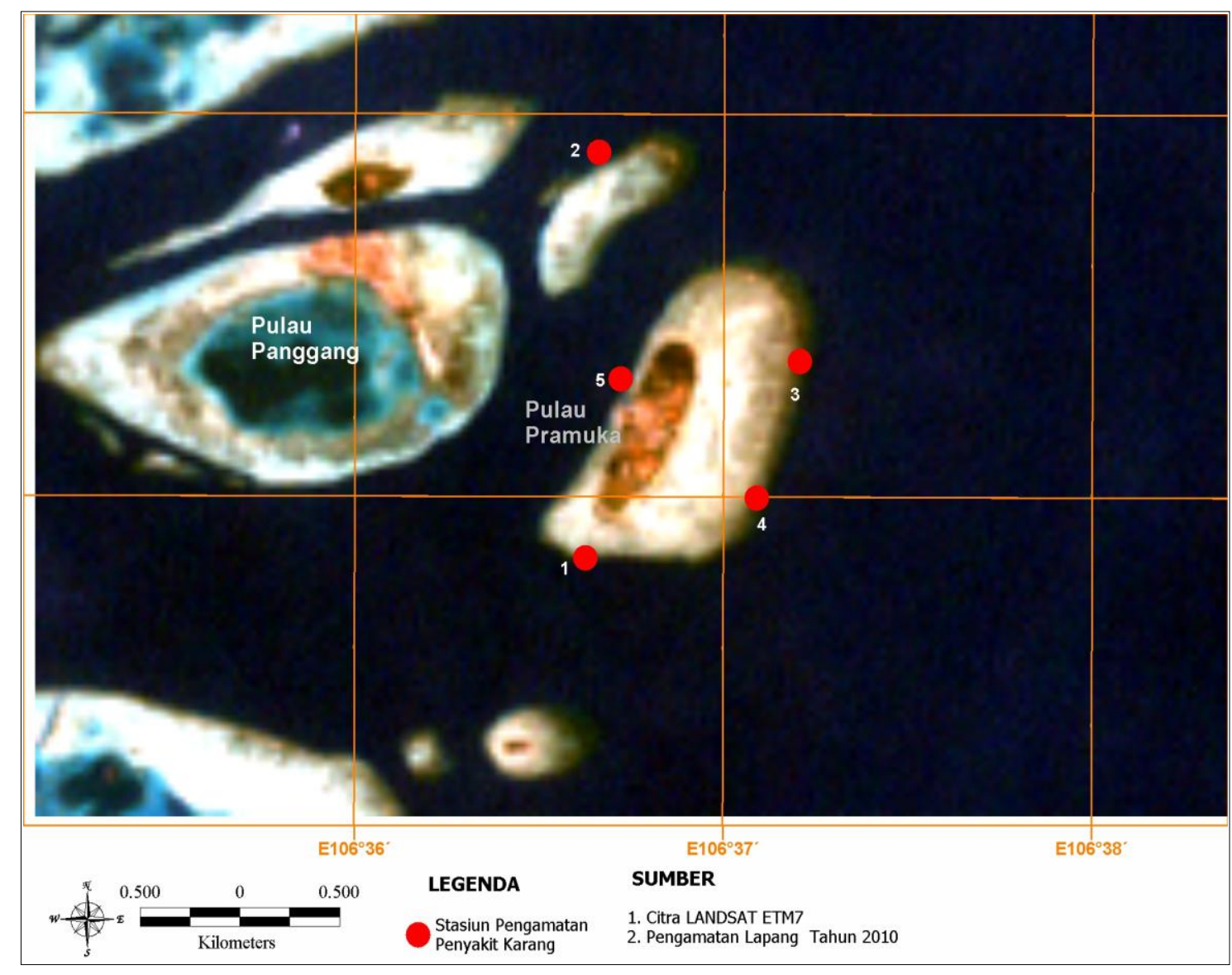

Gambar 1. Peta lokasi stasiun pengamatan

Tabel 1. Titik koordinat stasiun pengamatan

\begin{tabular}{|l|l|l|l|}
\hline No. & \multicolumn{1}{|c|}{ Stasiun pengamatan } & \multicolumn{1}{|c|}{ Latitude } & \multicolumn{1}{c|}{ Longitude } \\
\hline 1 & Barat Daya Pramuka & $05^{\circ} 45^{\prime} 10,2^{\prime \prime}$ & $106^{\circ} 36^{\prime} 38,02^{\prime \prime}$ \\
2 & APL & $05^{\circ} 44^{\prime} 6,54^{\prime \prime}$ & $106^{\circ} 36^{\prime} 38,68^{\prime \prime}$ \\
3 & Timur Laut Pramuka & $05^{\circ} 44^{\prime} 39,12^{\prime \prime}$ & $106^{\circ} 37^{\prime} 11,68^{\prime \prime}$ \\
4 & Timur Pramuka & $05^{\circ} 45^{\prime} 0,3^{\prime \prime}$ & $106^{\circ} 37^{\prime} 4,99^{\prime \prime}$ \\
5 & Dermaga 1 & $05^{\circ} 44^{\prime} 41,46^{\prime \prime}$ & $106^{\circ} 36^{\prime} 42,44^{\prime \prime}$ \\
\hline
\end{tabular}

\section{HASIL DAN PEMBAHASAN}

Marga dari karang Fungiidae yang ditemukan di stasiun penelitian di Pulau Pramuka ada lima, yaitu Heliofungia, Herpolitha, Fungia, Ctenactis, dan Sandalolitha. Marga yang paling banyak ditemukan adalah Fungia dan yang paling jarang ditemukan adalah Heliofungia. Lokasi yang memiliki keragaman Marga yang tinggi adalah pada Timur Laut Pramuka, yaitu sebanyak 5 marga, dan yang paling kecil keragamannya adalah pada Dermaga 1, yaitu sebanyak 3 marga (Gambar 2).
Pada stasiun Barat Daya Pramuka hanya ditemukan 4 marga dari Fungiidae, yaitu 1 individu Herpolitha, 20 individu Fungia, 10 individu Ctenactis, dan 3 individu Sandalolitha. Pada stasiun Area Perlindungan Laut (APL) ditemukan 4 marga dari Fungiidae yaitu 22 individu Fungia, 5 individu Ctenactis, 5 individu Herpolitha, dan 1 individu Sandalolitha. Timur Laut Pramuka merupakan stasiun yang memiliki nilai keragaman yang paling tinggi karena ditemukan 5 Marga dari Fungiidae, yaitu 9 individu Fungia, 4 individu Ctenactis, 2 individu Herpolitha, 2 individu Sandalolitha, dan 1 individu 
Heliofungia. Pada stasiun Timur Pramuka ditemukan 4 marga dari Fungiidae, yaitu 6 individu Fungia, 4 individu Herpolitha, 3 individu Ctenactis, dan 1 individu Heliofungia. Pada Dermaga 1 hanya ditemukan 3 marga karang Fungiidae, yaitu 4 individu Fungia, 2 individu Ctenactis dan 1 individu Herpolitha. Walaupun Timur
Laut Pramuka merupakan stasiun yang paling tinggi keragamannya, namun Fungiidae paling berlimpah pada stasiun Barat Daya Pramuka yaitu sebanyak 34 individu karang Fungiidae. Fungia merupakan marga yang paling berlimpah pada seluruh stasiun pengamatan. Sedangkan Heliofungia merupakan marga yang paling jarang ditemukan.

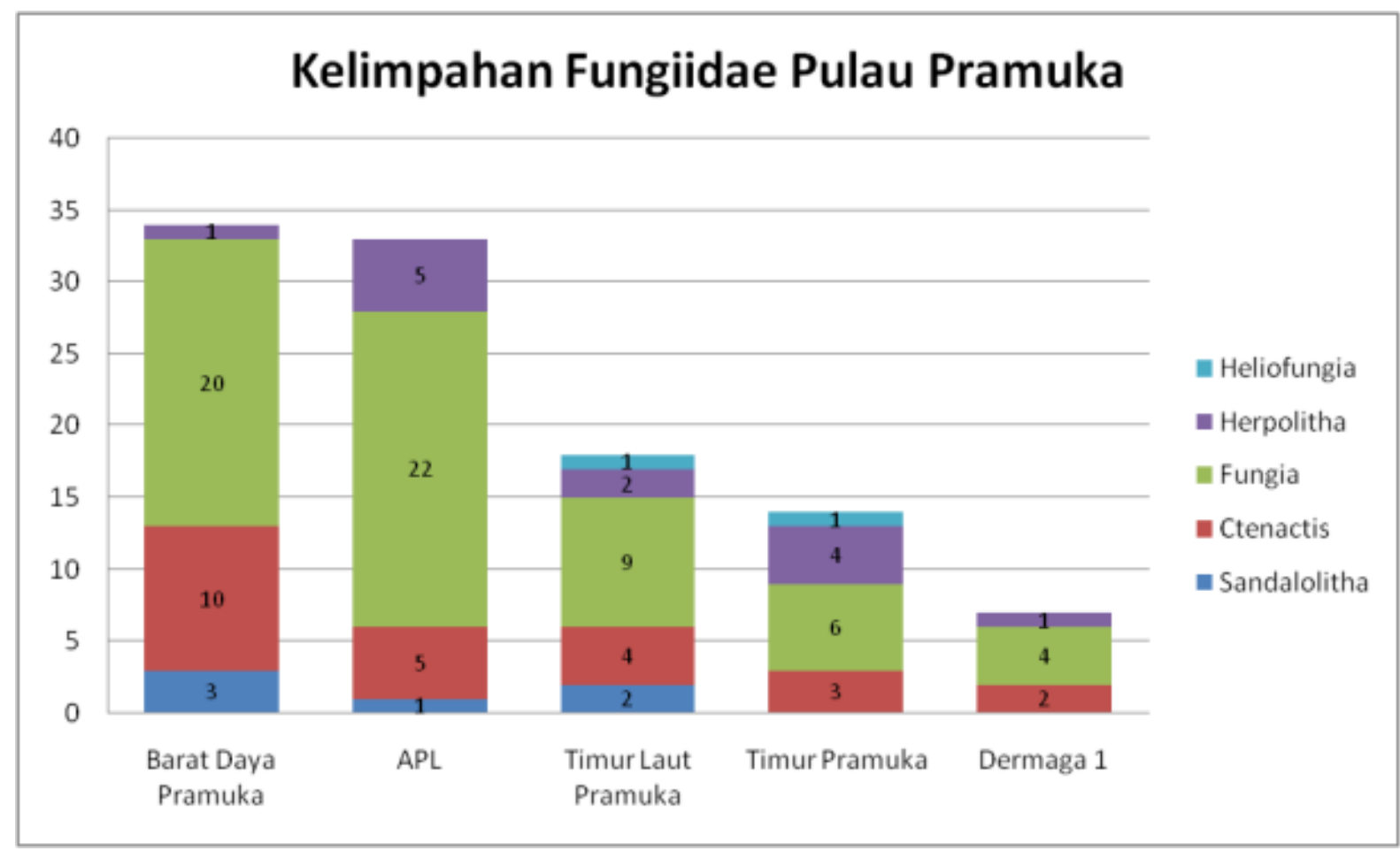

Gambar 2. Grafik kelimpahan karang Fungiidae di Pulau Pramuka

Tabel 2. Kondisi kesehatan tiap marga dari karang Fungiidae di Pulau Pramuka

\begin{tabular}{|c|c|c|c|c|c|c|c|c|c|c|c|}
\hline \multicolumn{12}{|c|}{ (individu) } \\
\hline \multirow{2}{*}{$\begin{array}{l}\text { Marga } \\
\text { Lokasi }\end{array}$} & \multicolumn{2}{|c|}{ Sanda-lolitha } & \multicolumn{2}{|c|}{ Ctenac-tis } & \multicolumn{2}{|c|}{ Fungia } & \multicolumn{2}{|c|}{ Herpo-litha } & \multicolumn{2}{|c|}{ Helio-fungia } & \multirow{2}{*}{$\begin{array}{c}\text { Total } \\
\text { Fungiidae } \\
\end{array}$} \\
\hline & Sehat & Sakit & Sehat & Sakit & Sehat & Sakit & Sehat & Sakit & Sehat & Sakit & \\
\hline $\begin{array}{c}\text { Barat Daya } \\
\text { Pramuka }\end{array}$ & \multirow[t]{2}{*}{2} & 1 & 4 & 6 & 7 & 13 & 1 & & & & 34 \\
\hline APL & & 1 & 1 & 4 & 5 & 17 & 3 & 2 & & & 33 \\
\hline $\begin{array}{c}\text { Timur Laut } \\
\text { Pramuka }\end{array}$ & \multirow[t]{3}{*}{1} & \multirow[t]{3}{*}{1} & 1 & 3 & 4 & 5 & 2 & & 1 & & 18 \\
\hline $\begin{array}{c}\text { Timur } \\
\text { Pramuka }\end{array}$ & & & \multirow[t]{2}{*}{1} & 2 & 2 & 4 & 2 & 2 & 1 & & 14 \\
\hline Dermaga 1 & & & & 2 & 1 & 3 & & 1 & & & 7 \\
\hline $\begin{array}{c}\text { Total } \\
\text { Marga } \\
\end{array}$ & 3 & 3 & 7 & 17 & 19 & 42 & 8 & 5 & 2 & 0 & 106 \\
\hline
\end{tabular}


Tabel 3. Penyakit karang yang muncul pada tiap marga

\begin{tabular}{|c|c|c|c|c|c|c|c|c|}
\hline \multirow{2}{*}{ Marga } & \multirow{2}{*}{ YBD } & \multirow{2}{*}{ SD } & \multirow{2}{*}{ YBD+SD } & \multirow{2}{*}{ ES } & \multicolumn{4}{|c|}{ Bleaching } \\
\hline & & & & & Patches & Spots & Stripes & Full \\
\hline Sandalolitha & \multirow{5}{*}{ - } & \multirow{5}{*}{$\bullet$} & \multirow{5}{*}{ - } & \multirow{5}{*}{$\bullet$} & \multirow{5}{*}{$\begin{array}{l}\bullet \\
\bullet \\
\bullet\end{array}$} & \multirow{5}{*}{$\begin{array}{l}\bullet \\
\bullet\end{array}$} & \multirow{5}{*}{ • } & \multirow{5}{*}{$\begin{array}{l}\bullet \\
\bullet\end{array}$} \\
\hline Ctenactis & & & & & & & & \\
\hline Fungia & & & & & & & & \\
\hline Herpolitha & & & & & & & & \\
\hline Heliofungia & & & & & & & & \\
\hline
\end{tabular}

Penyakit karang paling banyak menjangkit pada marga Fungia. Dari total 61 individu Fungia yang terdata di perairan Pulau Pramuka, hanya 19 individu $(31,15 \%)$ saja yang masih dalam kondisi sehat dan 42 individu (68,85\%) terkena penyakit karang. Pada lokasi Area Perlindungan Laut (APL) paling banyak ditemukan Fungia yang terserang penyakit, yaitu 17 individu $(77,27 \%)$ dan hanya 5 Fungia (22,73\%) yang sehat. Pada Fungia ditemukan Yellow Band Disease, sedimentasi, pemutihan karang dengan pola patches dan full, serta gabungan penyakit Yellow Band Disease dengan sedimentasi dalam satu individu.

Ctenactis merupakan marga dari suku Fungiidae kedua yang paling banyak terkena penyakit karang setelah marga Fungia. Sebanyak 24 individu karang Ctenactis ditemukan di seluruh stasiun pengamatan di Pulau Pramuka, 17 individu $(70,83 \%)$ di antaranya terkena penyakit karang. Lokasi yang paling banyak ditemukan Ctenactis yang terserang penyakit adalah pada stasiun Barat Daya Pramuka dengan jumlah 6 individu $(60 \%)$ terserang penyakit dan 4 individu (40\%) dalam kondisi sehat. Pada Ctenactis ditemukan Yellow Band Disease, pemutihan karang dengan semua pola (patches, spots, stripes, dan menyeluruh) dan gabungan penyakit Yellow Band Disease dengan sedimentasi dalam satu individu.

Herpolitha menempati urutan ketiga yang paling banyak terkena penyakit karang. Jumlah karang Herpolitha yang ditemukan adalah 13 individu, dimana 5 individu $(38,46 \%)$ terkena penyakit karang dan 8 individu $(61,54 \%)$ dalam kondisi sehat. Enlarge Structure (ES) hanya ditemukan pada Marga Herpolitha. Selain ES, ditemukan juga Yellow Band Disease menyerang pada Herpolitha.

Total karang Sandalolitha yang ditemukan di semua stasiun pengamatan di Pulau Seribu adalah 6 individu. Sebanyak 3 individu (50\%) karang Sandalolitha didata dalam kondisi terkena penyakit karang dan 3 individu dalam kondisi sehat (50\%). Pada Sandalolitha hanya pemutihan karang yang muncul dengan pola patches dan spots.

Heliofungia merupakan satusatunya marga karang dari Fungiidae di semua stasiun pengamatan di Pulau Pramuka yang tidak ditemukan terjangkit penyakit karang.

Secara keseluruhan, walaupun Fungia merupakan marga yang paling banyak terkena penyakit, namun Ctenactis merupakan marga yang memiliki nilai persentase terkena penyakit karang yang lebih besar karena jumlah individu Fungia lebih banyak daripada Ctenactis.

Dari total 106 individu karang Fungiidae yang ditemukan di 5 stasiun pengamatan di Pulau Pramuka, sebanyak $38,68 \%$ (41 individu) dalam kondisi sehat dan $61,32 \%$ (65 individu) terserang penyakit karang (Gambar 3). Penyakit karang yang teridentifikasi menyerang Fungiidae pada kelima stasiun yaitu Yellow Band Disease, pemutihan karang (bleaching), sedimentasi, gabungan antara sedimentasi dan Yellow Band Disease, dan Enlarge Structure.

Penyakit karang yang paling banyak muncul adalah Yellow Band Disease (YBD), yaitu sebesar 67,69\% dari total penyakit karang yang ditemukan pada Fungiidae. Nilai kelimpahan Yellow Band Disease yaitu sebesar 0,37 individu $/ \mathrm{m}^{2}$. 
Yellow Band Disease menyerang Fungiidae terlihat di Bali tahun 2005, tetapi dua tahun berikutnya terdapat sedikit kasus aktif namun banyak yang mati. Di Thailand dan Filipina, kedua kejadian kasus aktif dan banyak karang yang mati telah terlihat, di Gili Trawang, Indonesia pada Desember 2007 hampir semua Fungiidae terinfeksi secara aktif tetapi hanya sedikit karang yang mati (Cervino et al., 2008). YBD yang telah menginfeksi bangunan terumbu karang Montastrea spp. pada umumnya, telah tercatat di Karibia dan dapat menyebar sekitar 0,5-1,0 cm per bulan (Cervino et al., 2001).

YBD di Fungia spp. muncul sebagai noda (blotch) yang membentuk lingkaran yang meluas tapi tidak pernah terlihat membentuk cincin melingkar. Pada tahap berikutnya (setelah lesi kuning menghilang), degradasi jaringan utuh muncul dan pewarnaan merah muda di bawah jaringan terletak pada kerangka terlihat jelas (Cervino et al., 2008).

Telah ditunjukkan hubungan yang jelas antara peningkatan nilai dari penyebaran YBD dan suhu permukaan laut yang tinggi. Lesi Yellow Blotch muncul di perairan dengan suhu 26$28^{\circ} \mathrm{C}$ (Cervino et al., 2008). Kepadatan zooxanthellae berkurang ketika karang stres akibat suhu dan terinfeksi bakteri YBD. Ketika kombinasi pathogenik dan stres akibat suhu, alga menjadi semakin tua (senescent) dalam jaringan tuan rumahnya dan tidak dilepaskan. Alga simbiotik lebih sensitif pada suhu dan patogen yang dikombinasikan daripada hanya stres akibat suhu.

YBD selalu ditemukan tidak hanya pada satu individu dari Fungiidae yang berkumpul (berkoloni) berdasarkan pengamatan yang telah dilakukan. Menurut Cervino et al. (2008), peningkatan nilai penyebaran YBD ketika sudah terinfeksi dapat berkembang baik di kondisi normal maupun ketika suhu permukaan laut tinggi. $\mathrm{Hal}$ ini menimbulkan dugaan bahwa pathogen yang menyebabkan YBD mudah menulari karang yang berada di dekatnya.

Penyakit kedua yang paling banyak ditemukan pada karang Fungiidae di Pulau Pramuka adalah pemutihan karang (bleaching) yaitu sebesar 18,46\%. Pemutihan karang ini dibagi menjadi empat jenis, yaitu spots, stripes, patches, dan menyeluruh (Gambar 4). Bleaching dijelaskan sebagai dissosiasi hubungan simbiotik antara hewan karang dan alga endosimbiotik fotosintesisnya karang tersebut, zooxanthellae (Iglesias-Periato, 1997; Brown, 1997). Karang bleaching umumnya dipertimbangkan sebagai penyakit yang disebabkan oleh tekanan lingkungan seperti kenaikan suhu air laut (Brown et al., 1996; Glynn, 1993), penurunan suhu air laut (Coles and Fadlallah, 1991; Gates et al., 1992), peningkatan radiasi solar (Fisk and Done, 1985; Gleason and Wellington, 1993), polusi (Mitchell and Chet, 1975), penurunan salinitas (Fang et al., 1995), dan kombinasi dari tekanan-tekanan ini (Brown et al., 1995; Lesser et al., 1990). Pada karang yang terkena bleaching (pemutihan karang), karang ini masih hidup sehingga polip masih terlihat. Struktur terumbunya tidak terkikis atau ditempati oleh alga karena jaringannya masih ada. Batas antara bagian yang memutih dengan jaringan yang sehat biasanya berlainan (Beeden et al., 2008). Nilai kelimpahan pemutihan karang sebesar 0,10 individu $/ \mathrm{m}^{2}$.

Sedimentasi merupakan penyakit yang ketiga terbanyak yang ditemukan pada Fungiidae di Pulau Pramuka $(9,23 \%)$. Sedimentasi mempengaruhi karang dalam beberapa cara: (1) mengakibatkan kematian dengan menutupi atau mengubur (Loya, 1976; Cortes and Risk, 1985; Riegl, 1995); (2) menurunkan pertumbuhan karang dewasa dengan abrasi dan bayangan (shading) (Roy and Smith, 1971; Aller and Dodge, 1974); (3) menekan densitas zooxanthellae dan aktivitas fotosintesis, dan meningkatkan respirasi dan produksi mucus (Riegl and Branch, 1995; Yentsch et al., 2002); (4) mengurangi reproduksi karang, penempelan larva karang, dan ketahanan hidup awal karang (Kojis and Quinn, 1984; Hodgson, 1990; Babcock and Davies, 1991); (5) mengakibatkan degradasi karang dengan menyebabkan kematian melalui berlimpahnya sedimen atau penguburan oleh sedimen, dan kemudian menekan pertumbuhan dari koloni dewasa yang bertahan hidup melalui peningkatan persaingan dengan alga (Nugues and Roberts, 2003). Nilai kelimpahan sedimentasi yaitu sebesar $0,05 \mathrm{individu} / \mathrm{m}^{2}$. 


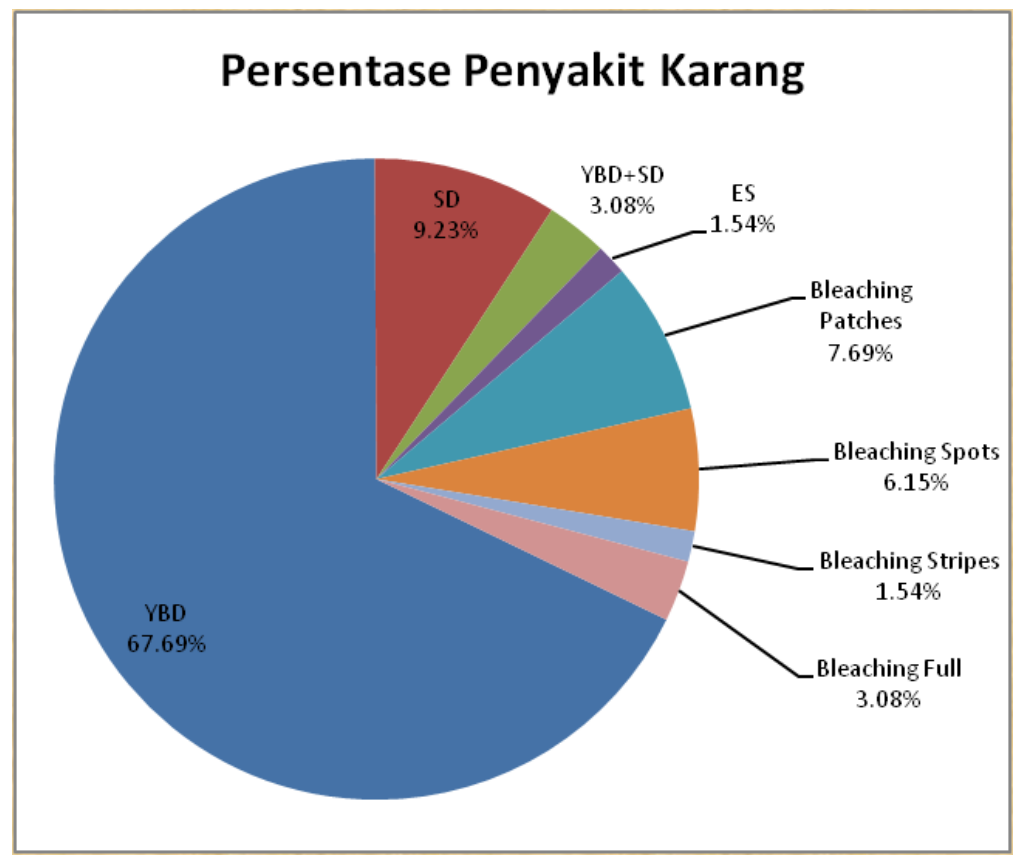

Gambar 3. Persentase kelimpahan penyakit karang di Pulau Pramuka

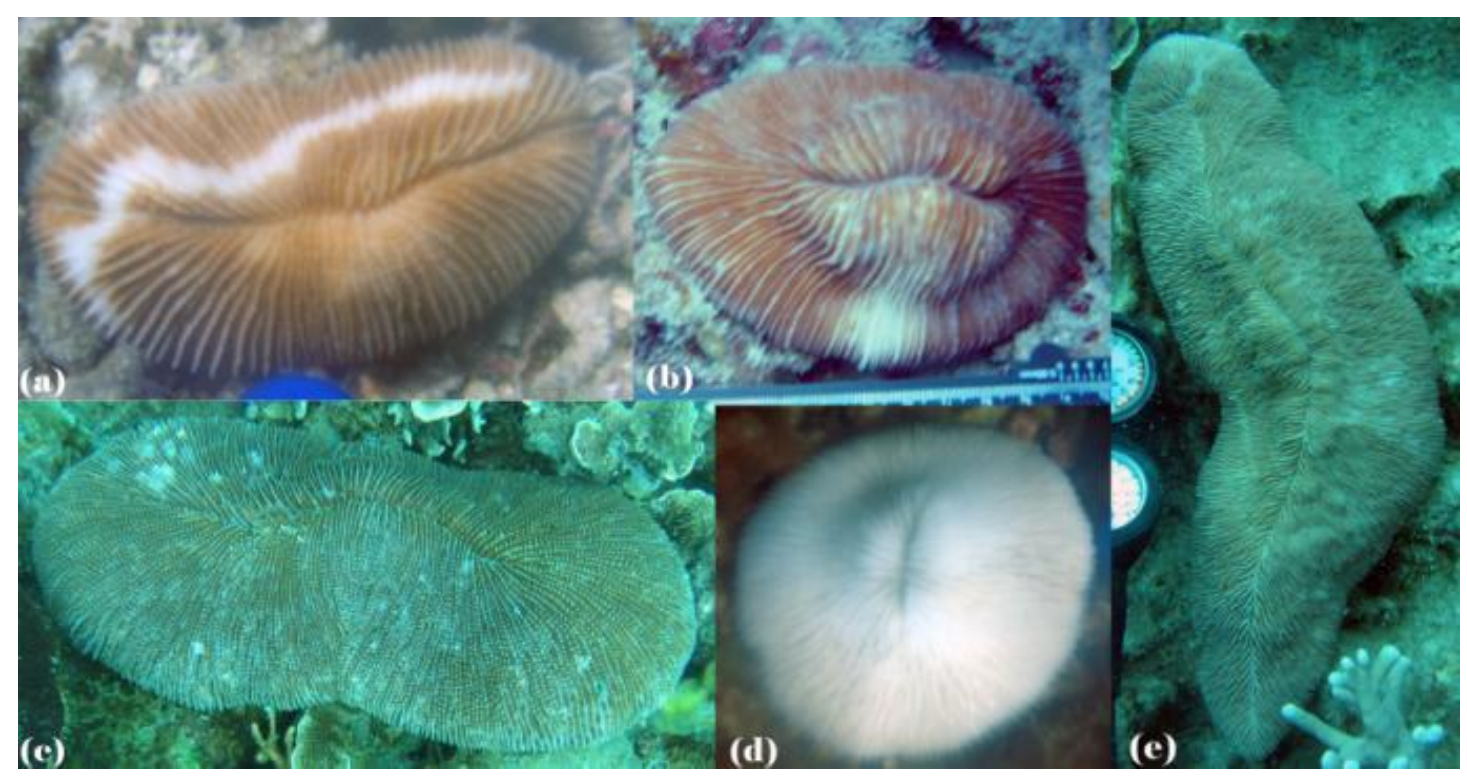

Gambar 4. Fungiidae sehat dan terkena bleaching yang ditemukan di Pulau Pramuka (a) stripes (b) patches (c) spots (d) menyeluruh (e) sehat

Pada stasiun pengamatan ditemukan sebanyak 2 individu Fungiidae $(3,08 \%)$ terjangkit dua penyakit karang, yaitu Yellow Band Disease dan sedimentasi, dalam 1 individunya (Gambar 5). Hal ini diduga dapat terjadi dalam dua kemungkinan. Dugaan pertama karang tersebut terjangkit Yellow Band Disease terlebih dahulu, kemudian lama kelamaan bagian tubuhnya yang terkena YBD mati sehingga ditutupi oleh sedimen. Dugaan lainnya yaitu karang tersebut terkena sedimentasi terlebih dahulu membuat kondisi karang mudah diserang oleh pathogen YBD. Nilai kelimpahan Yellow Band Disease dan sedimentasi yaitu sebesar 0,02 individu $/ \mathrm{m}^{2}$. 
Enlarge Structure hanya ditemukan pada 1 individu (1,54\%) dari 106 Fungiidae di stasiun pengamatan Pulau Pramuka. Enlarga Structure masuk dalam kategori pertumbuhan tidak normal (growth anomalie).

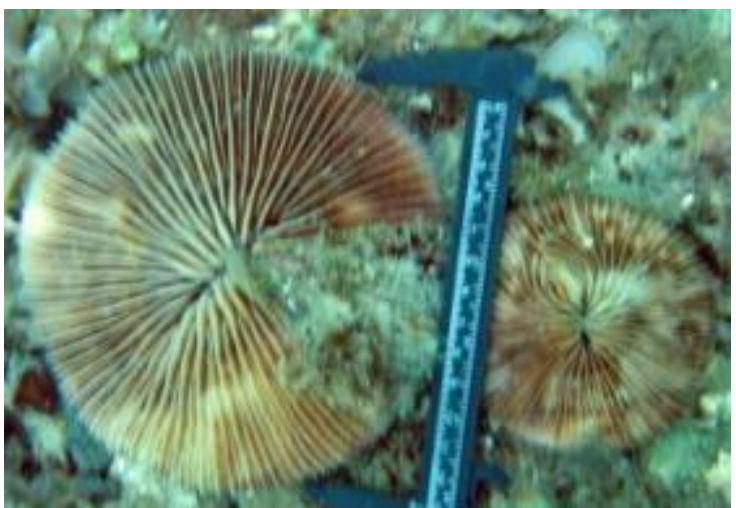

Gambar 5. Individu $\begin{gathered}\text { Fungiidae } \\ \text { terjangkit }\end{gathered}$ YBD+SD
Fungia di Timur Pramuka

Pertumbuhan yang tidak normal (growth anomalies) banyak ditemukan pada Acropora sp., dan secara mikroskopis, biasanya tercatat sebagai hyperplasia dari grastovascular canal. Tidak ada tanda-tanda neoplasia, yang biasanya dicirikan oleh pertumbuhan yang tak terkontrol dari sel anaplastic pleomorphic dengan nucleoli yang terlihat jelas, bentuk mitotic, dan terkadang dengan jaringan yang hilang (Work, 2005). Peters et al. (1986) menggambarkan pertumbuhan tidak normal pada Acropora sp. di Karibia sebagai calicoblastic neoplasma berdasarkan proliferasi dari calicoblastic epidermis mengakibatkan hilangnya seluruh polip normal. Penyebab lain dari pertumbuhan karang yang tak normal yaitu oleh organisme (seperti polychaetes atau jamur/algae) dimana beberapa jenis karang dapat merespon gangguan organisme tersebut melalui pertumbuhan skeletal yang berlebihan (Wielgus dan Glassom, 2002). Nilai kelimpahan Enlarge Structure yaitu sebesar 0,01 individu $/ \mathrm{m}^{2}$.

\section{KESIMPULAN}

Barat Daya Pramuka merupakan lokasi yang memiliki kelimpahan Fungiidae paling tinggi, namun keragaman Fungiidae tertinggi berada pada lokasi Timur Laut Pramuka.
Pada stasiun penelitian di Pulau Pramuka terdata ada lima marga dari karang Fungiidae, yaitu Heliofungia, Herpolitha, Fungia, Ctenactis, dan Sandalolitha. Marga yang paling banyak ditemukan adalah Fungia dan yang paling jarang ditemukan adalah Heliofungia. Stasiun Barat Daya Pramuka merupakan lokasi dengan jumlah Fungiidae yang paling banyak, namun Timur Laut Pramuka merupakan lokasi yang paling tinggi keragamannya. Fungia merupakan marga karang yang paling banyak ditemukan terjangkit penyakit, namun nilai persentase terkena penyakit karang terbesar adalah Ctenactis.

Sebanyak $38,68 \% \quad(41$ individu) dalam kondisi sehat dan $61,32 \% \quad(65$ individu) terserang penyakit karang. Penyakit karang yang teridentifikasi menyerang Fungiidae pada kelima stasiun yaitu Yellow Band Disease, pemutihan karang (bleaching), sedimentasi, gabungan antara sedimentasi dan Yellow Band Disease, serta Enlarge Structure. Yellow Band Disease merupakan penyakit karang yang paling banyak muncul, yaitu sebesar $67,69 \%$ dari total penyakit karang yang ditemukan pada Fungiidae.

\section{DAFTAR PUSTAKA}

Aller R.C. and Dodge R.E. 1974. Animalsediment relations in a tropical lagoon-Discovery Bay, Jamaica. J Mar Res 32:209-232.

Babcock, R.C. and Davies, P. 1991. Effects of sedimentation on settlement of Acropora millepora. Coral Reefs 9:205-208.

Banin,E.,Israely, T.,Fine, M.,Loya,Y., Rosenberg, E.,2001a. Role of endosymbiotic zooxanthellae and coral mucus in the adhesion of the coral-bleaching pathogen Vibrio chiloi to its host. FEMS Microbiology Letters 199,33-37.

Beeden, R., Willis, Bette L., Raymundo, Laurie J., Page, Cathie A., Weil, Ernesto. 2008. Underwater Cards for Assessing Coral Health on IndoPacific Reefs. CRTR Program Project Executing Agency, Centre for Marine Studies, Gerhmann Building, The University of Queensland, St Lucia, Qld 4072, Australia. 
Brown, B.C. 1997. Coral bleaching: causes and consequences. Proc 8th Int Coral Reef Symp 1:65-74.

Brown, B.E., Dunne, R.P., Chansang, H. 1996. Coral bleaching relative relative to elevated seawater temperature in the Andaman Sea (Indian Ocean). Over the last 50 years. Coral Reefs 15: 151-152.

Brown, B., Le Tissier, M.D.A., Bythell, J. 1995. Mechanisms of bleaching deduced from histological studies of reef corals sampled during a natural bleaching event. Mar Biol 122:655-663.

Bryant, D., Burke, L., McManus, J. \& Spalding, M., 1998. Reefs at risk: a map-based indicator of threats to the World's coral reefs. Washington, DC: World Resource Institute.

Cervino JM., Goreau TJ., Nagelkerken I., Smith GW., Hayes R. 2001. Yellow Band and Dark Spot Syndromes in caribbean Corals: Distribution, Rate of Spread, Cytology and Effects on Abundance and Dividion Rate of Zooxanthellae. Hydrobiologia 460: 53-63.

Cervino J.M., Thompson F.L., Gomez-Gil B., Lorence E.A., Goreau T.J., Hayes R.L., Winiarski-Cervino K.B., Smith G.W., Hughen K. and Bartels E.. 2008. the Vibrio core group induces YBD in Caribbean and Indo-Pacific reef-building corals. J Appl Microbiol ISSN 1364-5072.

Coles. S.L., Fadlallah, Y.H. 1991. Reef coral survival and mortality at low temperatures in the Arabian Gulf: new species-specific lower temperature limits. Coral Reefs 9:231-237.

Cortes, J.N., Risk, M.J. 1985. A reef under siltation stress: Cahuita, Costa Rica. Bull Mar Sci 36:339356.

Fang, L.-S., Wang, J.T., Lin, K.L. 1998. The subcellular mechanism of the release of zooxanthellae during coral bleaching. Proc of the Natl Scientific Council 22: 150-158.

Fisk, D.A., Done, T.J. 1985. Taxonomic and bathymetric patterns of leaching in corals, Myrmidon Reef (Queensland). In: Gabrié C, et al (eds) Proc 5th Int Coral Reef Congr, vol 6. Antenne Museum - EPHE, Moorea, French Polynesia, pp 149154.
Gates, R.D., Baghdasarian, G., Muscatine, L. 1992. Temperature stress causes host cell detachment in symbiotic cnidarians: implications for coral bleaching. Biological Bulletin (Woods Hole) 182: 324-332.

Gleason, D. F. and Wellington, G. M. 1993. Ultraviolet radiation and coral bleaching. Nature, 365: 836838.

Glynn, P.W. 1993. Coral-reef bleaching ecological perspective. Coral Reefs 12: 1-17.

Haapkylä, J., A.S. Seymour, J. Trebilco and D. Smith. 2007. Coral disease prevalence and coral health in the Wakatobi Marine Park, south-east Sulawesi, Indonesia. J. Mar. Biol. Ass. U.K., 87, 5582/1-12.

Hodgson, G. 1990. Sediment and the settlement of larvae of the reef coral Pocillopora damicornis. Coral Reefs 9:41-43.

Hoegh-Guldberg, O.,1999. Climate change, coral bleaching and the future of the world_s coral reefs. Marine and Freshwater Research, 50:839-866.

Iglesias-Prieto, R. 1997. Temperaturedependent inactivation of photosystem II in symbiotic dinoflagellates. Proc 8th Int Coral Reef Symp, Panama 2: 1313-1318.

Kojis, B.L., Quinn, N.J. 1984. Seasonal and depth variation in fecundity of Acropora palifera at two reefs in Papua New Guinea. Coral Reefs 3:165-172.

Lesser, M. P., Stochaj, W. R., Tapley, D. W. \& Shick, J. M. 1990. Bleaching in coral-reef anthozoans: effects of irradiance, ultraviolet radiation, and temperature on the activities of protective enzymes against active oxygen. Coral Reefs 8:225-232.

Loya, Y. 1976. Effects of water turbidity and sedimentation on the community structure of Puerto Rican corals. Bull Mar Sci 26:450466.

Mitchell, R. and Chet, I. 1975. Bacterial attack of corals in polluted seawater. Microb Ecol 2:227-233.

Nugues, M. M., Roberts, C. M. 2003. Coral mortality and interaction with algae in relation to sedimentation. Coral reefs (2003) 22: 507-516. 
Peters EC, Halas JC, McCarty HB (1986) Calicoblastic neoplasms in Acropora palmata, with a review of reports on anomalies of growth and form in corals. J Natl Cancer Inst 76:895-912.

Porter JW, Dustan P, Jaap WC, Patterson KL, Kosmynin V, Meier OW, Patterson ME, Parsons M (2001) Patterns of spread of coral disease in the Florida Keys. Hydrobiologia 460:1-24.

Riegl, B. 1995. Effects of sand deposition on scleractinian and alcyonacean corals. Mar Biol 121:517-526.

Riegl, B., Branch, G.M. 1995. Effects of sediment on the energy budgets of four scleractinian (Bourne 1990) and alcyonacean (Lamouroux 1816) corals. J Exp Mar Biol Ecol 186:259-275.

Roy, K.J., Smith, S.V. 1971. Sedimentation and coral reef development in turbid water: Fanning Lagoon. Pac Sci 25:234248.

Stedman TL. 2000. Stedman's medical dictionary, 27th edn.

Lippincott Williams \& Wilkins, BaltimoreSuharsono. 1998. Kesadaran masyarakat tentang terumbu karang (kerusakan karang di Indonesia). P3O-LIPI, Indonesia: $77 \mathrm{hlm}$.
Kathryn P. Sutherland, James W. Porter, Cecilia Torres. 2004. Disease and immunity in Caribbean and IndoPacific zooxanthellate corals. Mar Ecol Prog Ser Vol. 266: 273-302, 2004.

Veron J (1995) Corals in space and time. The biogeography and evolution of the Scleractinia. Comstock-Cornell Press, Ithaca, NY.

Wielgus J, Glassom D (2002) An aberrant growth form of red sea corals caused by polychaete infestations. Coral Reefs 21:315-316.

Work, T.M. and Rameyer, R.A. 2005. Characterizing lesions in corals from American Samoa. Coral Reefs 24: 384-390.

Yentsch, C.S., Yentsch, C.M., Cullen, J.J., Lapointe, B., Phinney, D.A., Yentsch, S.W. 2002. Sunlight and water transparency: cornerstones in coral research. J Exp Mar Biol Ecol 268:171-183. 